\title{
Spatial distribution of radiogenic heat in the Iullemmeden basin - Precambrian basement transition zone, NW Nigeria
}

\author{
Joseph Aisabokhae ${ }^{1}$, Moses Adeoye ${ }^{2}$ \\ ${ }^{1}$ Federal University Birnin Kebbi, Department of Applied Geophysics; Birnin Kebbi, Nigeria; \\ e-mail: joseph.aisabokhae@fubk.edu.ng (corresponding author); ORCID ID: 0000-0002-6894-8733 \\ ${ }^{2}$ Federal University Oye-Ekiti, Department of Geology; Oye-Ekiti, Nigeria; \\ e-mail: moses.adeoye@fuoye.edu.ng; ORCID ID: 0000-0002-2603-2276
}

(C) 2020 Authors. This is an open access publication, which can be used, distributed and reproduced in any medium according to the Creative Commons CC-BY 4.0 License requiring that the original work has been properly cited.

Received: 11 June 2020; accepted: 10 September 2020; first published online: 24 September 2020

\begin{abstract}
The area which transcends the Precambrian basement complex onto the Sokoto sector of the Iullemmeden basin in northwestern Nigeria presents a unique prospect for geothermal exploration research in the absence of regional heat production data, despite its tectonic history and depositional characteristics. In this study, geophysical exploration employing radiometric technique was adopted to classify the petrologic units within the fringes of the Iullemmeden basin and the adjoining crystalline basement complex so as to estimate the radiogenic heat potential within the terrain that may support geothermal considerations. Airborne radiometric measurements acquired over the area were digitized and processed to obtain radioelement concentration maps and the $\mathrm{K} / \mathrm{Th} / \mathrm{U}$ ternary map. Results show that the ranges of measured concentrations of ${ }^{40} \mathrm{~K},{ }^{238} \mathrm{U}$ and ${ }^{232} \mathrm{Th}$ are 4.6 to $18.9 \%, 0.7$ to $4.9 \mathrm{ppm}$ and 4.6 to $18.9 \mathrm{ppm}$ respectively. Radiogenic heat estimation derived from radioelement data within eight petrologic units comprising quaternary sediments, schist, carbonates, shale/clay, younger granites, older granites, gneissic rock and migmatite showed that the lowest radiogenic heat production estimates ranging from $0.27-0.66 \mu \mathrm{W} \cdot \mathrm{m}^{-3}$ were recorded in the sedimentary terrain within the quaternary sediments while the highest radiogenic heat production values of between 2.04 to $2.34 \mu \mathrm{W} \cdot \mathrm{m}^{-3}$ were recorded in the basement complex within gneissic rocks. The spatial distribution of radiogenic heat in the area showed an increased heat gradient within the basement complex and a diminishing heat gradient over the Iullemmeded basin.
\end{abstract}

Keywords: radiogenic heat, radiometry, geothermal exploration, basement complex, Iullemmeden basin, northwestern Nigeria

\section{INTRODUCTION}

Radiometric methods in geophysical prospecting measure naturally occurring radioactivity emitted in the form of gamma rays. Gamma radiation mostly originates from petrologic units containing radioactive isotopes of potassium $\left({ }^{40} \mathrm{~K}\right)$, thorium $\left({ }^{232} \mathrm{Th}\right)$ and uranium $\left({ }^{238} \mathrm{U}\right)$ (Dentith \& Mudge 2014). Airborne gamma-ray spectrometry has been effectively used in geological mapping
(Elkhadragy et al. 2016), mineral exploration (Darnley 1973), peat mapping (Gatis et al. 2019) and radiogenic heat production studies (Sabra et al. 2019) in recent years. Airborne surveys are flown on regular grid along parallel lines which are spaced depending on the survey application. Radiometry has several characteristics that make it unique, especially in the context of mapping soil types for environmental studies. The measured radioactivity emanates from the top few 
centimeters of the earth crust and has a limited ability to incorporate the signatures of deep-seated anomalies. The radiometric data are used to map variations in the chemical rather than physical characteristics of an area because it is possible to identify the elemental source of the radiation from the energy of the gamma-ray emitted (Dentith \& Mudge 2014). The energy is a conversion of mass through radioactive decay processes and a substantial amount of this energy is converted to radiogenic heat (Abbady 2010). The energy which escapes during the decay process is the kinetic energy exhibited by emitted particles and gamma radiation. The radioactive elements of interest suitable in setting up a heat flow system are potassium, thorium and uranium, among other elements which make a much smaller contribution (Rybach et al. 1977, Vila et al. 2010, Adagunodo et al. 2019). The conversion process of measured radioactivity into elemental concentrations of petrological surface units, involves a multi-stage reduction of the data to isolate or suppress responses of a non-geological origin. A larger content of the reduction process is empirical and the knowledge of the characteristics of radioactivity is needed to understand its basis, applicability and limitations.

The application of radioactivity to study some environmental factors related to human health, environmental contamination and water pollution have been performed in northwestern Nigeria (Girigisu et al. 2013, Ibrahim et al. 2013, Bello et al. 2016, Usikalu et al. 2017). However, there are limited studies targeted at estimating the radiogenic heat potential of the contrasting lithotypes and their spatial representation in the region. The study area defines a zone where the Iullemmeden basin, which spans $700,000 \mathrm{~km}^{2}$ extending from Mali and the western boundary of the Republic of Niger through the Benin Republic into northwestern Nigeria, terminates gently over the crystalline basement rocks of Precambrian age (Fitches et al. 1985). The basement rocks consist of igneous and metamorphic rocks, whereas the Iullemmeden basin in its entirety is a cratonic basin of mostly conformable formations created by tectonic epeirogenic movements within cratonic rocks (Kogbe 1979). This display of complex aggregation of conformable and unconformable formation overlap within the basin and crystalline basement respectively, is likely to present a unique heat flux system with a sizeable contribution from ${ }^{40} \mathrm{~K}$ radioisotope and decay series of ${ }^{232} \mathrm{U}$ and ${ }^{238} \mathrm{Th}$. Studies on radioactive heat generation have been widely published around the world targeting isolated cases involving sedimentary, metamorphic or igneous rocks (Rybach et al. 1977, Sharma 1994, Mukai 1999, Salem et al. 2005, Abbady 2010, Abbady \& Al-Ghamdi 2018), nevertheless, studies employing geophysical techniques for surface rocks in northwestern Nigeria is still insufficient. This paper presents results on the spatial representation of radioactive heat production of several lithotypes within the interface of the Iullemmeden basin and crystalline basement in northwestern $\mathrm{Ni}$ geria using radiometric data.

\section{GEOLOGICAL SETTING}

The region located within the northwestern $\mathrm{Ni}$ geria, is an extensive area of regional-scale highgrade metamorphism with an estimated area of $1,100 \mathrm{~km}^{2}$. The area lies between latitude from $11^{\circ} 30^{\prime}$ to $12^{\circ}$ north of Equator and longitude from $4^{\circ} 30^{\prime}$ to $5^{\circ}$ east of Equator (Fig. 1) and is characterized by hills, plateaus, and adjoining southern lowlands. The petrological imprint comprises a wide range of sedimentary, igneous and metamorphic rocks ranging in age from Eocene (56-33.9 Ma) to Precambrian (600 $\pm 150 \mathrm{Ma}$ ) (Ogezi 1977, Kogbe 1979, Rahaman 1988). The eastern part is dominated by massive quartzite over an extensive area towards the Funtua River flowing from Katsina State. Surficial rocks which are well exposed in the western part include metaconglomerates which contain rounded deformed pebbles and cobbles of quartzite in a matrix of schist (Ramadan \& Abdel Fattah 2010). The presence of conglomerates and deep-seated quartzite suggests a littoral or continental environment which is consistent with its position situated around the eastern margin of the region containing Proterozoic sediments (Kogbe 1979).

The Precambrian basement complex, which constitutes about $65 \%$ of the study area, has been extensively discussed and classified in recent times (Garba 2003, Ramadan \& Abdel Fattah 2010, Aisabokhae 2019, Aisabokhae \& Oresajo 2019). The major rock units within the basement 
complex include gabbroic rocks, younger granites, older granites, felsic gneiss, migmatite and undifferentiated metavolcanics. The progression of deposition from the most recent is Gamba Formation, Kalambaina, Formation, Dange Formation, Wurno Formation, Dukamaje Formation, Taloka Formation and Gundumi Formation (Kogbe 1979).

Structurally, the area is situated in a highly strained zone with observable deformation and foliated country rocks which are affected by the brittle-ductile shear zone in the region. The prevailing tectonic orientation is the NE-SW dipping cleavage which is mainly an isoclinal fold. Multiple successive regimes of deformation have resulted in isoclinal folding and cleavage development in the area. Other structural patterns such as a NW-SE sinistral conjugate systems as a result of Late Pan-African brittle deformation are present (Aisabokhae 2019, Olasunkanmi et al. 2020).

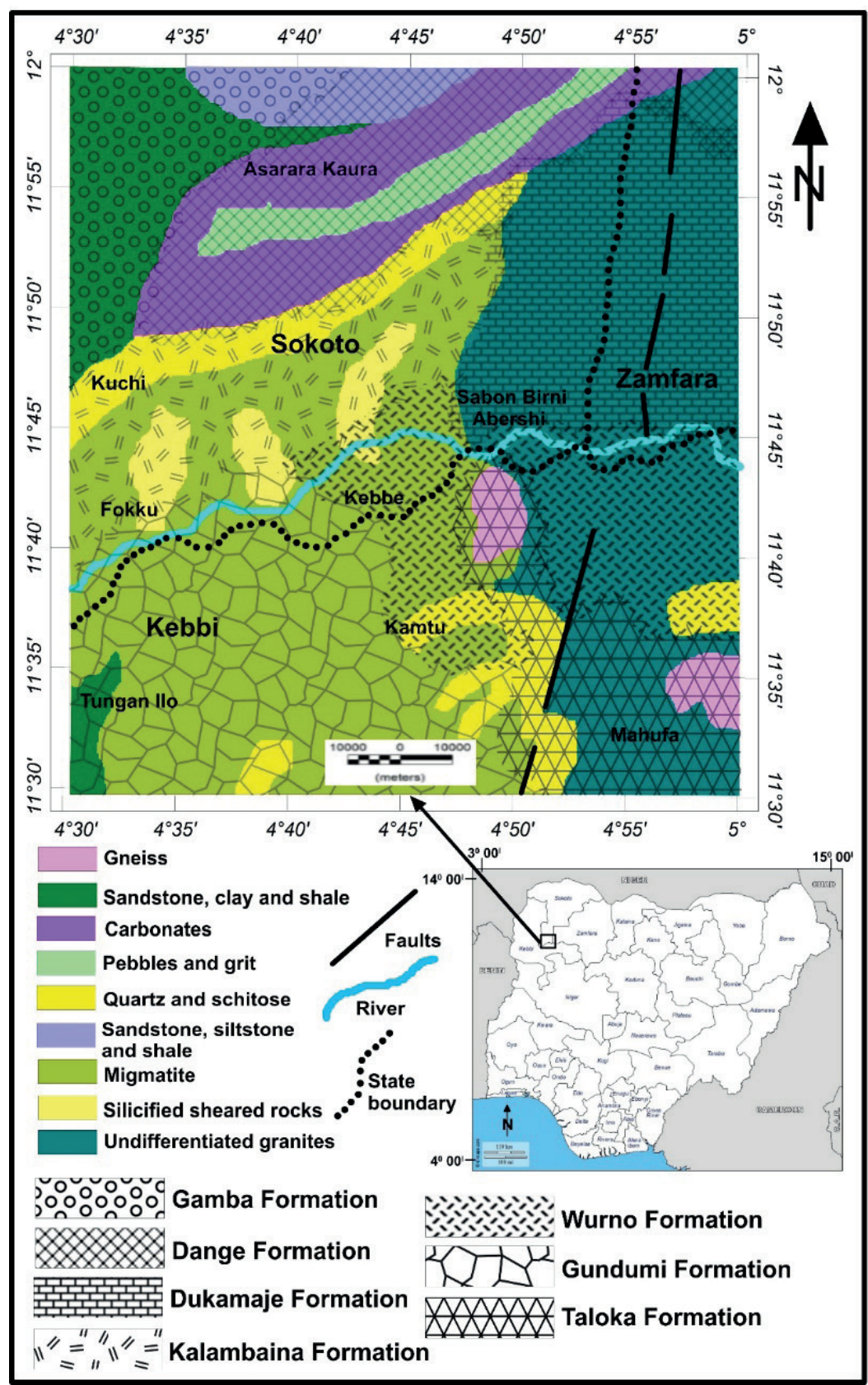

Fig. 1. Geological map of the area (NGSA) 


\section{DATA AND METHODS}

The data used in this work comprised of thorium, uranium and potassium concentration measurements of the study area within northwestern Nigeria. The data was acquired from Nigeria Geological Survey Agency (NGSA) Abuja, Nigeria which carried out aero-radiometric survey of Nigeria from 2004 to 2009. The spectrometer-mounted aircraft was flown at an average altitude of $81.6 \mathrm{~m}$ with line spacing and tie-line spacing set at $0.5 \mathrm{~km}$ and $5 \mathrm{~km}$ respectively. The dataset of Fokku with sheet number 73 were acquired in WGS 84 , UTM $32^{\circ} \mathrm{N}$ and were subsequently repositioned to UTM $31^{\circ} \mathrm{N}$ using the Geosoft Oasis Montaj software.

The gridded data was entered into Oasis Montaj, a geospatial software, to process each radioactive element. Composition imaging was performed on the three radioelement maps to display the uniqueness of their relative degree of concentration. Sum-normalization techniques are a way to combine all three-radioelement data in a bid to display the non-relative dominance of each element while the ternary image combines all three radioelement maps to accentuate their absolute dominance within the study area. Structural parameters such as minimum, maximum, arithmetic mean (X), standard deviation (SD) and coefficient of variability (CV) of each petrological unit and formation was computed to serve as input for further data analysis. If the $\mathrm{SD}$ is large, then the data is more dispersed. Meanwhile, the CV which checked the normality of each rock unit was calculated using Equation (1):

$\mathrm{CV}=100 \cdot \frac{\mathrm{SD}}{\mathrm{X}}$

Heat is produced when converted from energy during radioactive decay. The contributions of the decay series of ${ }^{232} \mathrm{Th},{ }^{238} \mathrm{U}$ and the radioactive isotope ${ }^{40} \mathrm{~K}$ are of geological importance in calculating radiogenic heat production. Estimation of radioactive heat production of various rock units was calculated $\left(A\right.$ in $\left.\mu \mathrm{W} \cdot \mathrm{m}^{-3}\right)$ by applying the relation performed in previous studies (Beamish \& Busby 2016, Vila et al. 2010) such that:

$A=10^{-5} \cdot \rho(3.48 \mathrm{~K}+2.56 \mathrm{Th}+9.52 \mathrm{U})$

where $\rho$ is the bulk density of the rock (Manger 1963, Saxov \& Abrahamsen 1964, Vila et al. 2010),
${ }^{232} \mathrm{Th}$ and ${ }^{238} \mathrm{U}$ are measured in ppm, and ${ }^{40} \mathrm{~K}$ measured in weight percent. The spatial distribution maps were generated using the open-source code QGIS 2.18.

\section{RESULTS AND DISCUSSION}

\section{Potassium concentration map}

In this study, several processed radioelement images have been analyzed to delineate the various lithological units within the area of study as well as to characterize petrologic constituents based on the radioelement dominance of surface and near surface rocks. Potassium, the most abundant of the three radioactive elements in the petrologic setting is an alkali element and occurs mainly in alkali feldspars, micas, and illite. The potassium concentration map (Fig. 2) shows three distinct levels of analyzed radioactive element.

The first level is represented by deep blue to light green colors and ranged from 4.66 to $6.37 \%$. This low-level concentration is dominant in the northwestern part of the area associated with clastic rocks of the Kalambaina Formation. The second level is the intermediate level depicted in colors between deep green and yellow, and predominantly displayed in the northeastern part of the study area. This level shows potassium percentages from 7.31 to $8.92 \%$ and is depictive of younger granites, schist and carbonates. The third level showed high ${ }^{40} \mathrm{~K}$ concentration ranging from 10.24 to $18.79 \%$ and is displayed in colors orange and pink. This level is interpretive of older granites, gneissic rocks and migmatites.

\section{Thorium concentration map}

The thorium concentration map (Fig. 3) displayed four levels of thorium concentrations. The low-level concentration recorded values from 4.67 to $6.10 \mathrm{ppm}$ and is displayed in blue and light green colors on the map. The low concentration region which dominates the northwestern axis coincided with quaternary sediments within the Gamba Formation. The second intermediate level (6.33 to $8.24 \mathrm{ppm}$ ) which displayed green and bright yellow colors was recorded over parts of the carbonate deposits, schist and younger granites in the northeastern part of the study area. 


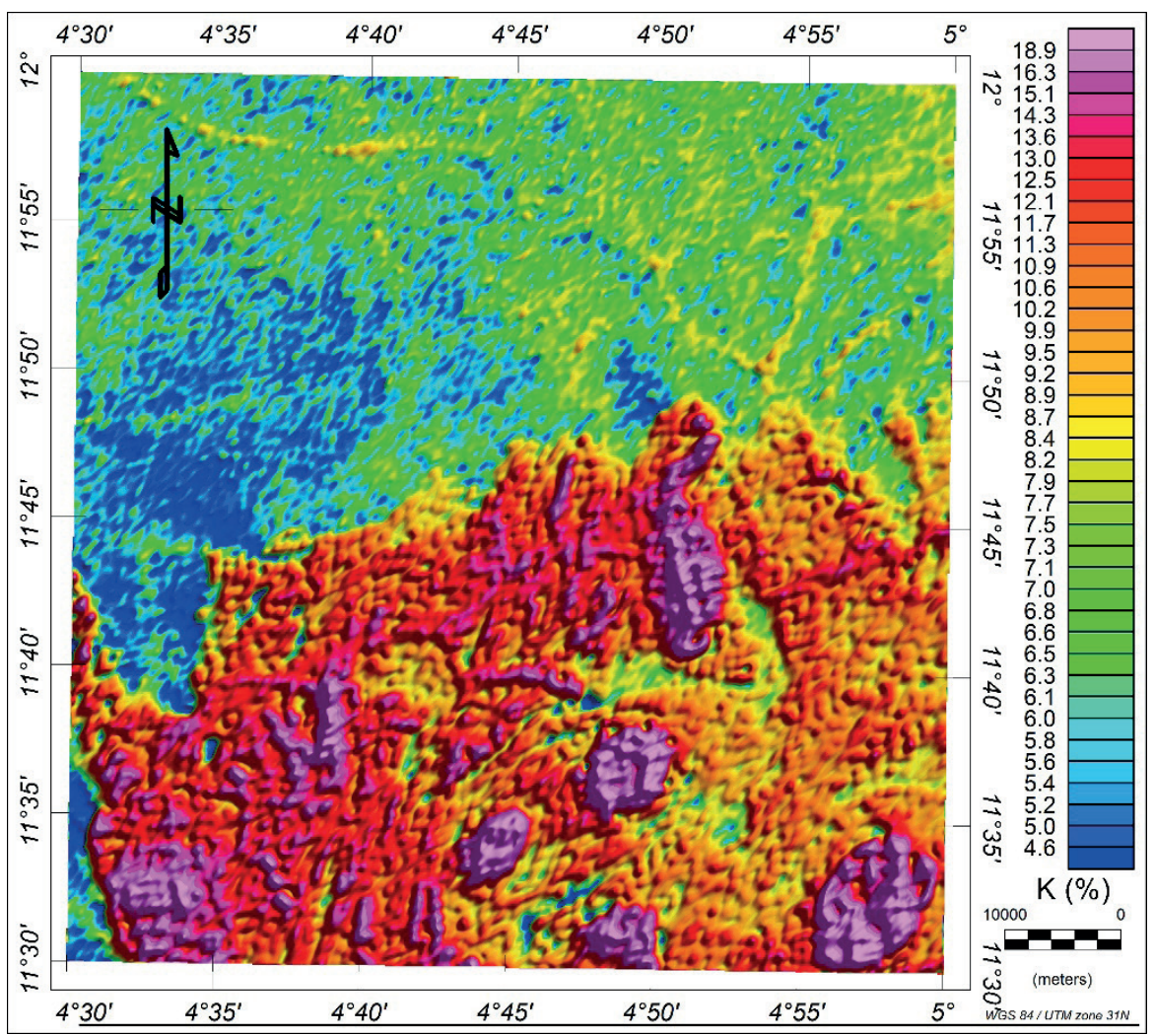

Fig. 2. Potassium concentration map

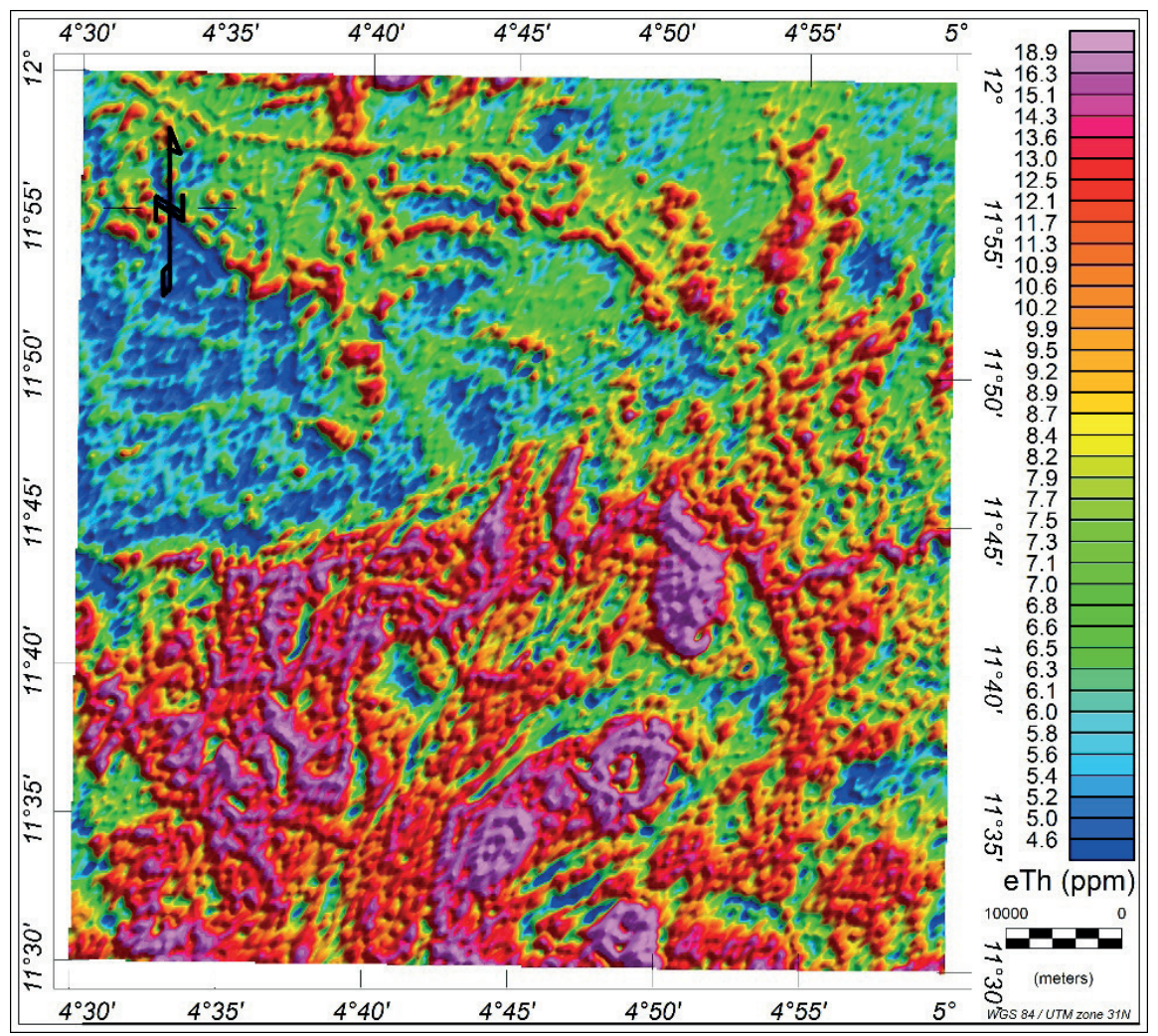

Fig. 3. Thorium concentration map 
The third level showing Th-concentration values ranging from 8.41 to $13.60 \mathrm{ppm}$ encountered migmatite and gneissic rocks predominantly in the southwestern part of the study area while the highest level of ${ }^{232} \mathrm{Th}$ concentration with values from 14.33 to $18.9 \mathrm{ppm}$ coincided with gneissic and migmatite emplacement in Figure 1.

\section{Uranium concentration map}

The uranium concentration showed three levels that are distinguishable in the area (Fig. 4). The first level is a low level of uranium concentration values ranging from 0.73 to $1.47 \mathrm{ppm}$ associated with clastic rocks including clays. The second level was recorded over some parts of the shale and younger granites rocks with concentration values between 1.97 and $2.63 \mathrm{ppm}$ while the third level showed concentration values of between 2.73 and $4.88 \mathrm{ppm}$ primarily associated with some kinds of clays, older granites, migmatite and schists.

\section{Absolute concentrations of radioelements}

The ternary image shows the total gamma ray response calculated from the radionuclides in the study area (Fig. 5). Reddish portions of the map are zones of potassium dominance indicating feldspathic enrichment. This signature is emphasized in the Taloka Formation where older granites are present. The greenish coloration depicts thorium dominance observable across the Wurno and Gundumi Formations comprising basement rocks in the study area. A blue coloration, observed predominantly in isolated pockets in the upper half of the area, showed uranium concentration depictive of carbonates, clays and quaternary sediments within the study area.

Areas displayed in white showed high concentration of all the three radioelements while the dark portions showed low concentration of the radioelements (IAEA 2003). Darkened portions are may depict carbonates or clay formations due to low radioactivity especially if chloromitic (Dentith \& Mudge 2014). The surrounding high levels of uranium showing a bluish coloration may be as a result of the organic matter content of the carbonates. Most evaporites are also poorly radioactive. Similarly, coals are among the least radioactive sediments (Amadi 2012). Migmatite-granite rocks show very high concentrations of uranium, thorium and potassium and may be sources of the whitish ternary display in the study area. Certain intermediate colorations such as purple are displayed in the ternary image which depicts the presence of uranium and thorium and the absence of potassium. High-silica rocks formed during the end phases of igneous differentiation, such as pegmatites, have high uranium and thorium concentrations compared to potassium (Ahmad 1998).

\section{Geostatistics of the petrological units}

The mean and standard deviation of the measured radiation parameters were established under normal distribution. Hence, all statistical analyses were performed using parametric statistical methods (Reda et al. 2020). The results of the statistical parameters of the datasets categorized as minimum values, maximum values, averages (arithmetic mean), standard deviation and coefficient of variation are presented in Table 1. The lowest mean concentration of ${ }^{40} \mathrm{~K}$ given as $5.51 \%$ was recorded within schist domain. Schist also presented the lowest mean concentration of ${ }^{232} \mathrm{Th}$ given as $5.67 \mathrm{ppm}$ while the lowest mean concentration of ${ }^{238} \mathrm{U}$ given as $0.92 \mathrm{ppm}$ was recorded within quaternary sediments. The highest mean concentration of ${ }^{40} \mathrm{~K}$ given as $15.16 \%$ was recorded within gneissic rock. ${ }^{232} \mathrm{Th}$ showed the highest mean concentration of $12.12 \mathrm{ppm}$ within migmatite and gneissic rocks while the highest mean concentration of ${ }^{238} \mathrm{U}$ given $3.25 \mathrm{ppm}$ was recorded within migmatite emplacement. These measured values are similar to other ground radiometric measurements obtained within Nigeria (Adagunodo et al. 2019) and other parts of the world (Wang et al. 2005, Norden \& Forster 2006, Allan et al. 2013). A high coefficient of variance $(\mathrm{CV} \%>50)$ was only observed in ${ }^{238} \mathrm{U}$ concentration values within younger granites and quaternary sediments, while low variance $(\mathrm{CV} \%<50)$ values were observed in the radioelement concentrations of all other rock units. 


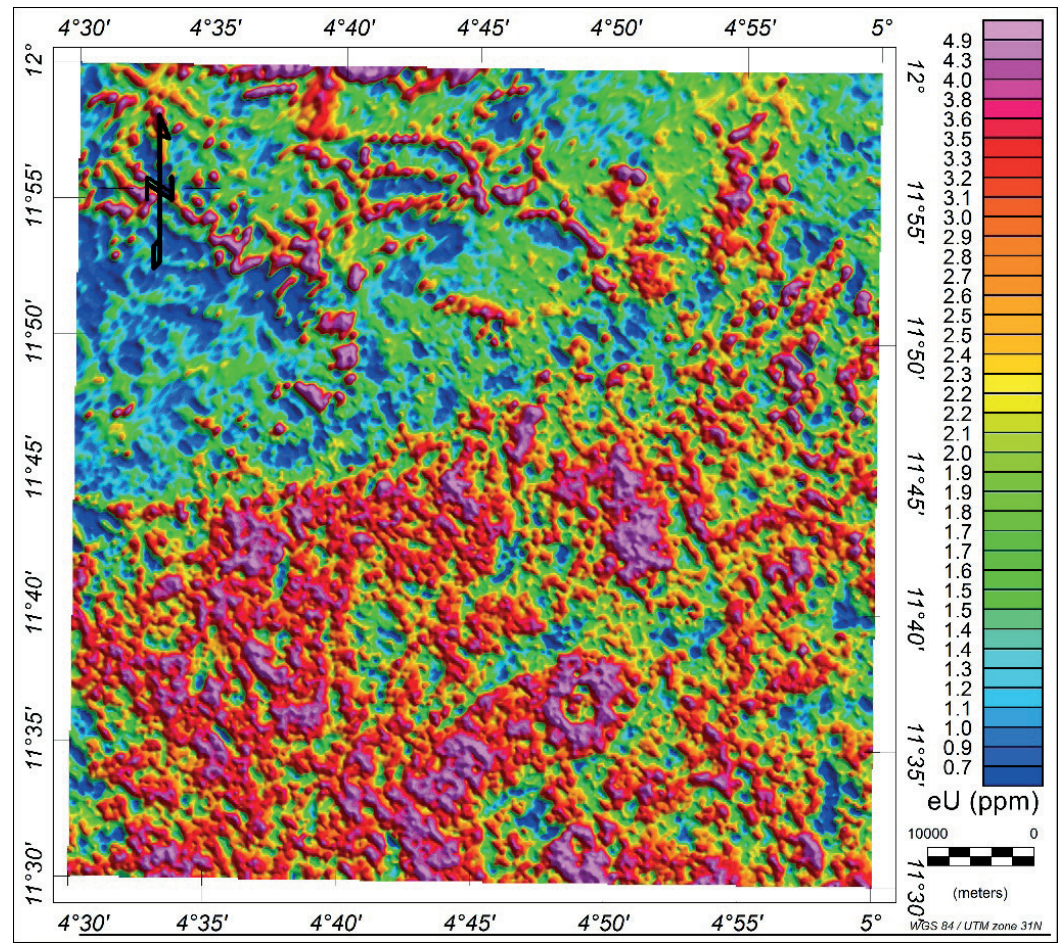

Fig. 4. Uranium concentration map

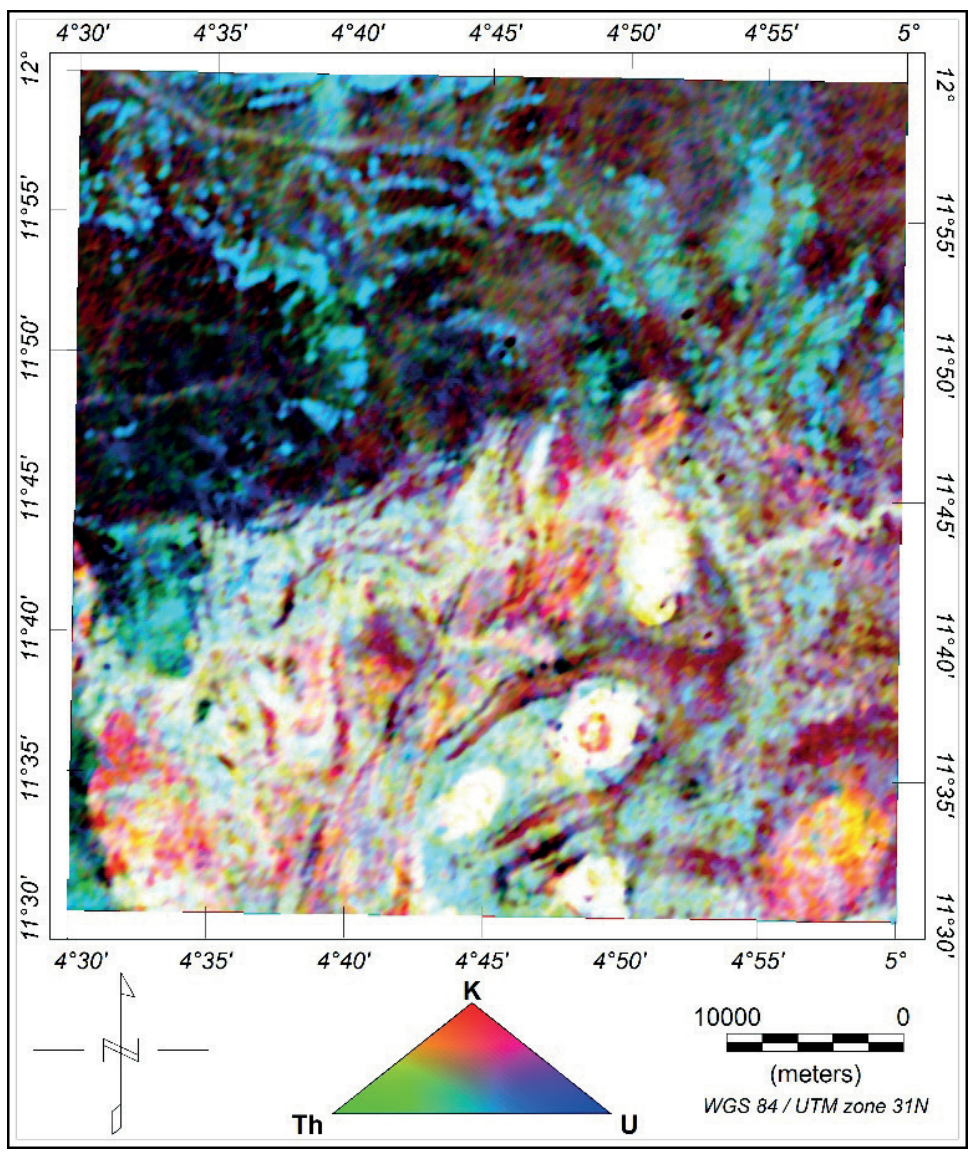

Fig. 5. Ternary map 
Table 1

Summary of the statistical treatments of gamma ray spectrometric data for the Precambrian basement rock units of NW Nigeria

\begin{tabular}{|c|c|c|c|c|}
\hline Rock unit & Statistical parameter & $\mathrm{K}[\%]$ & Th $[\mathrm{ppm}]$ & $\mathrm{U}[\mathrm{ppm}]$ \\
\hline Younger granite & $\begin{array}{c}\text { Min } \\
\text { Max } \\
\text { X } \\
\text { SD } \\
\text { CV\% }\end{array}$ & $\begin{array}{c}6.12 \\
8.41 \\
7.21 \\
1.15 \\
15.93\end{array}$ & $\begin{array}{c}7.03 \\
10.94 \\
8.33 \\
2.06 \\
24.75\end{array}$ & $\begin{array}{c}1.53 \\
2.64 \\
1.59 \\
1.04 \\
65.96\end{array}$ \\
\hline Older granite & $\begin{array}{c}\text { Min } \\
\text { Max } \\
\text { X } \\
\text { SD } \\
\text { CV\% }\end{array}$ & $\begin{array}{c}8.73 \\
11.74 \\
9.54 \\
1.66 \\
17.40\end{array}$ & $\begin{array}{c}6.33 \\
8.94 \\
6.54 \\
1.70 \\
26.04\end{array}$ & $\begin{array}{c}2.04 \\
2.69 \\
2.21 \\
0.50 \\
23.07\end{array}$ \\
\hline Schist & $\begin{array}{c}\text { Min } \\
\text { Max } \\
\text { X } \\
\text { SD } \\
\text { CV\% }\end{array}$ & $\begin{array}{c}4.64 \\
7.12 \\
5.51 \\
1.29 \\
23.45\end{array}$ & $\begin{array}{c}4.81 \\
9.90 \\
5.67 \\
3.05 \\
53.81\end{array}$ & $\begin{array}{c}1.77 \\
3.21 \\
2.10 \\
0.87 \\
43.08\end{array}$ \\
\hline Shale & $\begin{array}{c}\text { Min } \\
\text { Max } \\
\text { X } \\
\text { SD } \\
\text { CV\% }\end{array}$ & $\begin{array}{c}11.36 \\
18.49 \\
11.95 \\
4.46 \\
38.86\end{array}$ & $\begin{array}{c}9.21 \\
13.64 \\
10.01 \\
2.63 \\
26.26\end{array}$ & $\begin{array}{c}1.98 \\
3.14 \\
2.02 \\
0.79 \\
39.29\end{array}$ \\
\hline Gneissic rock & $\begin{array}{c}\text { Min } \\
\text { Max } \\
\text { X } \\
\text { SD } \\
\text { CV\% }\end{array}$ & $\begin{array}{c}14.31 \\
18.77 \\
15.16 \\
2.63 \\
17.30\end{array}$ & $\begin{array}{c}11.31 \\
13.63 \\
12.12 \\
1.21 \\
10.00\end{array}$ & $\begin{array}{l}2.73 \\
3.34 \\
3.05 \\
0.30 \\
9.84\end{array}$ \\
\hline Quaternary sediments & $\begin{array}{c}\text { Min } \\
\text { Max } \\
\text { X } \\
\text { SD }\end{array}$ & $\begin{array}{l}5.81 \\
7.73 \\
5.86 \\
1.32\end{array}$ & $\begin{array}{l}6.33 \\
6.33 \\
7.11 \\
0.63\end{array}$ & $\begin{array}{l}0.74 \\
1.71 \\
0.92 \\
0.57\end{array}$ \\
\hline Migmatite & $\begin{array}{c}\text { CV\% } \\
\text { Min } \\
\text { Max } \\
\text { X } \\
\text { SD } \\
\text { CV\% }\end{array}$ & $\begin{array}{c}22.57 \\
9.99 \\
16.41 \\
10.12 \\
4.45 \\
43.95 \\
\end{array}$ & $\begin{array}{c}8.89 \\
11.36 \\
13.94 \\
12.12 \\
1.39 \\
11.44 \\
\end{array}$ & $\begin{array}{c}62.44 \\
2.87 \\
4.03 \\
3.25 \\
0.61 \\
18.72 \\
\end{array}$ \\
\hline Carbonates & $\begin{array}{c}\text { Min } \\
\text { Max } \\
\text { X } \\
\text { SD } \\
\text { CV\% }\end{array}$ & $\begin{array}{c}6.13 \\
7.54 \\
6.89 \\
0.71 \\
10.16\end{array}$ & $\begin{array}{c}6.34 \\
7.73 \\
6.41 \\
0.93 \\
14.55\end{array}$ & $\begin{array}{l}1.53 \\
1.97 \\
1.59 \\
0.14 \\
4.40\end{array}$ \\
\hline
\end{tabular}

Explanations: Min - minimum, Max - maximum, X - mean, SD - standard deviation, CV\% - coefficient of variability in \%, K - potassium, $\mathrm{U}$ - uranium, Th - thorium.

\section{Radiogenic heat production}

The computation of radiogenic heat production in each rock unit comprising carbonates, quaternary sediments, schist, younger granite, older granite, shale, migmatite and gneissic rock was performed to determine the variability of heat production among the dominant rock types within the study area. The distribution of heat production over sedimentary rocks and crystalline basement rocks is given in Table 2. Calculated heat production for each element was performed to observe the ratio variability of each radioactive element towards the heat produced. The computed data showed that the sedimentary rocks generated relatively 
less quantity of heat ranging between 0.27 and $1.02 \mu \mathrm{W} \cdot \mathrm{m}^{-3}$ while the plutonic (basement) rocks composed predominantly of granite, migmatite and gneissic rocks presented enormously high total heat production values ranging from 1.10 to $2.34 \mu \mathrm{W} \cdot \mathrm{m}^{-3}$.

For the sedimentary units, two major factors that may have affected the radiation measurements are the nature of the source and the degree of maturity. A source that is rich in radioactive materials will necessarily produce radioactive sediments. However, a similar scenario may not occur with maturity. Some sediments may have radioelement concentration similar to their source, but as the sediments increasingly mature, new materials may be formed that may show reduced radioelement content. An example of this process is obtained in the transformation of greywackes into quartz (Dentith \& Mudge 2014). In each given rock unit, the radioactive heat production is governed by the contribution of ${ }^{40} \mathrm{~K},{ }^{232} \mathrm{Th}$ and ${ }^{238} \mathrm{U}$ as illustrated in Equation (2). The various rock types possess varying radioelement concentrations but similar geochemical behavior can be observed among them due to their sedimentation, magmatic differentiation or metamorphism phases (Cermak et al. 1982).

Results from other locations have presented relatively comparable values especially in crustal sedimentary rocks where heat production records were given to be between $0.33-1.80 \mu \mathrm{W} \cdot \mathrm{m}^{-3}$ (Salem et al. 2005) and within granitic plutons with heat production values ranging from 1.82 to $4.12 \mu \mathrm{W} \cdot \mathrm{m}^{-3}$ (Abbady \& Al-Ghamdi 2018). Plutonic rocks have been presented to have relatively higher rates of heat production in this study. Such notably increased heat production may be attributed to factors such as increased content of ${ }^{40} \mathrm{~K}$ isotope and degree of acidity occasioned as a result of increased radioactivity (Dentith \& Mudge 2014).

Table 2

Heat production from rock units

\begin{tabular}{|c|c|c|c|c|c|c|c|}
\hline \multirow{2}{*}{ Rock unit } & \multirow{2}{*}{$\begin{array}{c}\text { Latitude } \\
\text { (north) }\end{array}$} & \multirow{2}{*}{$\begin{array}{l}\text { Longitude } \\
\quad \text { (east) }\end{array}$} & \multirow{2}{*}{$\begin{array}{c}\text { Bulk density } \\
{\left[\mathrm{kg} / \mathrm{m}^{3}\right]}\end{array}$} & \multicolumn{4}{|c|}{ Heat Production $\left[\mu \mathrm{W} \cdot \mathrm{m}^{-3}\right]$ due to } \\
\hline & & & & $\mathbf{K}$ & Th & U & Total \\
\hline \multirow{3}{*}{$\begin{array}{l}\text { Quaternary } \\
\text { sediments }\end{array}$} & $11^{\circ} 59^{\prime} 06^{\prime \prime}$ & $4^{\circ} 45^{\prime} 15^{\prime \prime}$ & 1.2 & 0.0088 & 0.1883 & 0.0765 & 0.27 \\
\hline & $11^{\circ} 57^{\prime} 12^{\prime \prime}$ & $4^{\circ} 35^{\prime} 09^{\prime \prime}$ & 1.2 & 0.0100 & 0.2839 & 0.3667 & 0.66 \\
\hline & $11^{\circ} 55^{\prime} 21^{\prime \prime}$ & $4^{\circ} 40^{\prime} 17^{\prime \prime}$ & 1.2 & 0.0079 & 0.2439 & 0.1268 & 0.38 \\
\hline \multirow{3}{*}{ Schist } & $11^{\circ} 50^{\prime} 05^{\prime \prime}$ & $4^{\circ} 56^{\prime} 29^{\prime \prime}$ & 2.6 & 0.0139 & 0.4780 & 0.6123 & 1.10 \\
\hline & $11^{\circ} 47^{\prime} 09^{\prime \prime}$ & $4^{\circ} 54^{\prime} 17^{\prime \prime}$ & 2.6 & 0.0446 & 0.3533 & 0.6765 & 1.07 \\
\hline & $11^{\circ} 44^{\prime} 16^{\prime \prime}$ & $4^{\circ} 53^{\prime} 19^{\prime \prime}$ & 2.6 & 0.0638 & 0.4510 & 0.5942 & 1.11 \\
\hline \multirow{3}{*}{ Carbonates } & $11^{\circ} 47^{\prime} 23^{\prime \prime}$ & $4^{\circ} 35^{\prime} 11^{\prime \prime}$ & 1.6 & 0.0089 & 0.4469 & 0.3168 & 0.77 \\
\hline & $11^{\circ} 52^{\prime} 09^{\prime \prime}$ & $4^{\circ} 33^{\prime} 14^{\prime \prime}$ & 1.6 & 0.0100 & 0.1730 & 0.1005 & 0.28 \\
\hline & $11^{\circ} 50^{\prime} 17^{\prime \prime}$ & $4^{\circ} 44^{\prime} 06^{\prime \prime}$ & 1.6 & 0.0138 & 0.1985 & 0.2456 & 0.46 \\
\hline \multirow{3}{*}{ Shale/clay } & $11^{\circ} 49^{\prime} 04^{\prime \prime}$ & $4^{\circ} 47^{\prime} 17^{\prime \prime}$ & 2.3 & 0.0625 & 0.3393 & 0.5279 & 0.93 \\
\hline & $11^{\circ} 52^{\prime} 14^{\prime \prime}$ & $4^{\circ} 48^{\prime} 12^{\prime \prime}$ & 2.3 & 0.0954 & 0.5233 & 0.3997 & 1.02 \\
\hline & $11^{\circ} 58^{\prime} 04^{\prime \prime}$ & $4^{\circ} 45^{\prime} 03^{\prime \prime}$ & 2.3 & 0.0898 & 0.4176 & 0.4431 & 0.95 \\
\hline \multirow{3}{*}{ Younger granite } & $11^{\circ} 42^{\prime} 16^{\prime \prime}$ & $4^{\circ} 52^{\prime} 09^{\prime \prime}$ & 2.7 & 0.1052 & 0.7050 & 0.2853 & 1.10 \\
\hline & $11^{\circ} 40^{\prime} 27^{\prime \prime}$ & $4^{\circ} 39^{\prime} 19^{\prime \prime}$ & 2.7 & 0.1494 & 0.6815 & 0.6734 & 1.50 \\
\hline & $11^{\circ} 41^{\prime} 05^{\prime \prime}$ & $4^{\circ} 44^{\prime} 26^{\prime \prime}$ & 2.7 & 0.0310 & 0.5993 & 0.5526 & 1.18 \\
\hline \multirow{3}{*}{ Older granite } & $11^{\circ} 38^{\prime} 26^{\prime \prime}$ & $4^{\circ} 58^{\prime} 15^{\prime \prime}$ & 2.7 & 0.1276 & 0.9485 & 0.9381 & 2.10 \\
\hline & $11^{\circ} 43^{\prime} 18^{\prime \prime}$ & $4^{\circ} 57^{\prime} 06^{\prime \prime}$ & 2.7 & 0.0752 & 0.5488 & 0.5167 & 1.14 \\
\hline & $11^{\circ} 40^{\prime} 06^{\prime \prime}$ & $4^{\circ} 49^{\prime} 11^{\prime \prime}$ & 2.7 & 0.0945 & 0.5856 & 0.6131 & 1.29 \\
\hline \multirow{3}{*}{ Gneissic rock } & $11^{\circ} 35^{\prime} 27^{\prime \prime}$ & $4^{\circ} 55^{\prime} 22^{\prime \prime}$ & 2.8 & 0.0731 & 0.8989 & 1.0716 & 2.04 \\
\hline & $11^{\circ} 32^{\prime} 13^{\prime \prime}$ & $4^{\circ} 50^{\prime} 12^{\prime \prime}$ & 2.8 & 0.2452 & 0.8066 & 1.2595 & 2.31 \\
\hline & $11^{\circ} 31^{\prime} 23^{\prime \prime}$ & $4^{\circ} 59^{\prime} 03^{\prime \prime}$ & 2.8 & 0.1013 & 1.0795 & 1.1569 & 2.34 \\
\hline \multirow{3}{*}{ Migmatite } & $11^{\circ} 33^{\prime} 23^{\prime \prime}$ & $4^{\circ} 35^{\prime} 03^{\prime \prime}$ & 2.7 & 0.0733 & 0.7306 & 0.4468 & 1.25 \\
\hline & $11^{\circ} 35^{\prime} 23^{\prime \prime}$ & $4^{\circ} 39^{\prime} 03^{\prime \prime}$ & 2.7 & 0.0910 & 0.7199 & 0.6711 & 1.48 \\
\hline & $11^{\circ} 31^{\prime} 23^{\prime \prime}$ & $4^{\circ} 45^{\prime} 03^{\prime \prime}$ & 2.7 & 0.0893 & 0.6609 & 0.9001 & 1.65 \\
\hline
\end{tabular}




\section{Radiogenic heat distribution}

The distribution map obtained from the heat production analysis highlighted the variation in the levels of radiogenic heat (Fig. 6). The hotspots can be observed in the southeastern quadrant, especially around gneissic plutons where rock units showed the highest heat production values. Two distinct regions of heat production contrast can be observed in Figure 6. The areas showing low heat production values $0.27-1.10 \mu \mathrm{W} \cdot \mathrm{m}^{-3}$ are displayed in purple and dominantly featured in the northwestern axis of the study area while the areas with high heat production values ranging $1.11-2.34 \mu \mathrm{W} \cdot \mathrm{m}^{-3}$ are displayed in brown with increasing heat gradient extending from the NE-SW trending spine down to the southeastern axis of the study area. Both regions are demarcated by a NE-SW trending diagonal stretch of intermediate heat production values displayed in white and acting as the geologic boundary between the basin and the basement complex in the study area.

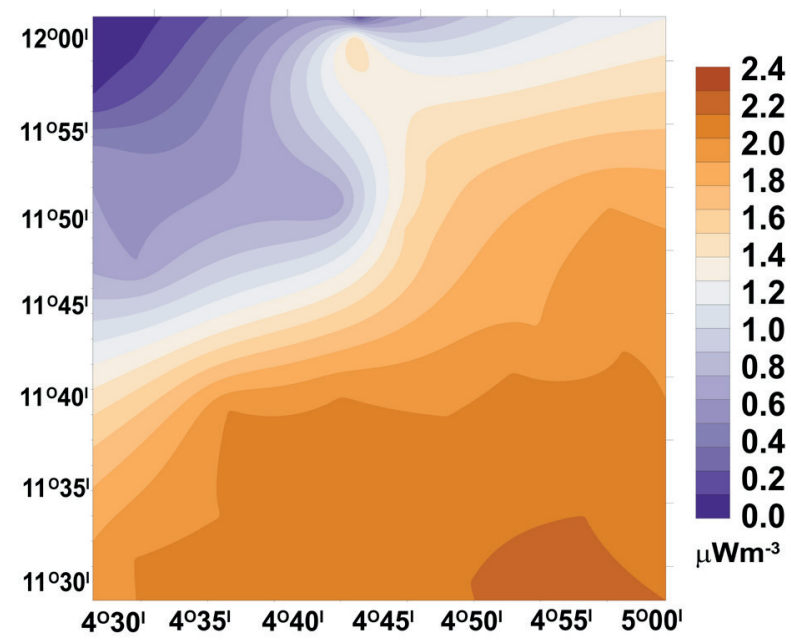

Fig. 6. Interpolation map for radiogenic heat production

The results of this study show that the RHP of quaternary sediments varied between 0.27 and $0.66 \mu \mathrm{W} \cdot \mathrm{m}^{-3}$, RHP values for schist recorded between 1.07 and $1.11 \mu \mathrm{W} \cdot \mathrm{m}^{-3}$ while carbonate and clay RHP values were in the range of 0.28 to $0.77 \mu \mathrm{W} \cdot \mathrm{m}^{-3}$ and 0.93 to $1.02 \mu \mathrm{W} \cdot \mathrm{m}^{-3}$ respectively. These rock units presented poor heat production indices towards geothermal consideration in the area. Plutonic rocks especially granitic rocks are presumed to have high radiogenic heat production capacities from several studies (Abbady \& El-Arabi 2006, Samwell 2010, Vila et al. 2010). The RHP values of younger granites were between 1.10 and $1.50 \mu \mathrm{W} \cdot \mathrm{m}^{-3}$ while older granites presented RHP values ranging from 1.14 to $2.10 \mu \mathrm{W} \cdot \mathrm{m}^{-3}$. Gneissic rocks presented the highest RHP values in the area ranging from 2.04 to $2.34 \mu \mathrm{W} \cdot \mathrm{m}^{-3}$ while migmatite showed RHP values between 1.25 and $1.65 \mu \mathrm{W} \cdot \mathrm{m}^{-3}$. RHP results from other locations around the globe have shown relatively comparable values especially in line with geothermal considerations of heat producing rocks as shown in Table 3.

Table 3

RHP values from other published studies

\begin{tabular}{|c|c|c|c|c|}
\hline S/N & Lithology & $\boldsymbol{A}\left[\boldsymbol{\mu W} \cdot \mathbf{m}^{-3}\right]$ & Location & Reference \\
\hline 1 & Granite & 9.53 & Egypt & $\begin{array}{c}\text { Abbady \& } \\
\text { El-Arabi } \\
2006\end{array}$ \\
\hline 2 & Granite & 3.20 & Egypt & $\begin{array}{c}\text { Abbady \& } \\
\text { Al-Ghamdi } \\
2018\end{array}$ \\
\hline 3 & Mafic rock & 0.74 & Norway & $\begin{array}{c}\text { Slagstad } \\
2008\end{array}$ \\
\hline 4 & $\begin{array}{c}\text { Granitic } \\
\text { rock }\end{array}$ & 2.94 & Norway & $\begin{array}{c}\text { Slagstad } \\
2008\end{array}$ \\
\hline 5 & $\begin{array}{c}\text { Meta- } \\
\text { sediments }\end{array}$ & 1.55 & Norway & $\begin{array}{c}\text { Slagstad } \\
2008\end{array}$ \\
\hline 6 & Granitoid & 2.60 & Australia & $\begin{array}{c}\text { Middleton } \\
2006\end{array}$ \\
\hline 7 & Sediments & 0.90 & Australia & $\begin{array}{c}\text { Middleton } \\
2006\end{array}$ \\
\hline
\end{tabular}

The radiogenic heat production capacity of the petrological units in the study area have been estimated between 0.27 and $2.34 \mu \mathrm{W} \cdot \mathrm{m}^{-3}\left(<4 \mu \mathrm{W} \cdot \mathrm{m}^{-3}\right)$ depictive of rocks with low geothermal character. Based on the available large data on RHP of rocks around the world, rocks with RHP values less than $4 \mu \mathrm{W} \cdot \mathrm{m}^{-3}$ are considered as low heat producing units. A range of values from 4 to $8 \mu \mathrm{W} \cdot \mathrm{m}^{-3}$ are proposed for moderate heat producing rocks while a proposed threshold of $8 \mu \mathrm{W} \cdot \mathrm{m}^{-3}$ was proposed for high heat producing rocks (Huston 2010, Gillespie et al. 2013). These classifications are, however, representative of exposed areas which show prevalent levels of erosion, thus volumetric insights are needed to estimate the total heat contribution. 


\section{CONCLUSION}

A regional systematic study of radiogenic activities was carried out over a basin-basement transition domain measuring an estimated $105,000 \mathrm{~km}^{2}$ within northwestern Nigeria. The study analyzed heat production rates and spectral gamma-ray data from the major petrologic units in the area across the sedimentary terrain and the plutonic emplacements. The result of this study showed that the RHP of quaternary sediments varied between 0.27 and $0.66 \mu \mathrm{W} \cdot \mathrm{m}^{-3}$ while schist recorded RHP values between 1.07 and $1.11 \mu \mathrm{W} \cdot \mathrm{m}^{-3}$. Carbonate and clay RHP values were in the range of 0.28 to $0.77 \mu \mathrm{W} \cdot \mathrm{m}^{-3}$ and 0.93 to $1.02 \mu \mathrm{W} \cdot \mathrm{m}^{-3}$ respectively. In the basement complex, RHP values of younger granites were between 1.10 and $1.50 \mu \mathrm{W} \cdot \mathrm{m}^{-3}$ while older granites presented RHP values ranging from 1.14 to $2.10 \mu \mathrm{W} \cdot \mathrm{m}^{-3}$. Gneissic rocks showed higher RHP character with values in the area ranging from 2.04 to $2.34 \mu \mathrm{W} \cdot \mathrm{m}^{-3}$ while migmatite showed RHP values between 1.25 and $1.65 \mu \mathrm{W} \cdot \mathrm{m}^{-3}$. In comparison with the global classification adopted in this study, the rocks in the area show low heat production character towards geothermal considerations. The results presented in this study show compelling evidence that radiogenic heat production is determined by the dominance of ${ }^{40} \mathrm{~K},{ }^{232} \mathrm{Th}$ and ${ }^{238} \mathrm{U}$ concentrations in the area.

\section{REFERENCES}

Abbady A., 2010. Evaluation of heat generation by radioactive decay of sedimentary rocks in Eastern Desert and Nile Valley, Egypt. Applied Radiation and Isotopes, 68, 10, 2010-2024.

Abbady A. \& El-Arabi A.M., 2006. Heat production rate from radioactive elements in igneous and metamorphic rocks in Eastern Desert. Egypt. Applied Radiation and Isotopes, 64, 131-137.

Abbady G.E. \& Al-Ghamdi A.H., 2018. Heat production rate from radioactive elements of granite rocks in north and southeastern Arabian Shield Kingdom of Saudi Arabia. Journal of Radiation Research and Applied Sciences, 11, 231-290. https://doi.org/10.1016/j.jrras.2018.03.002.

Adagunodo T.A., Bayowa O.G., Usikalu M.R. \& Ojoawo A.I., 2019. Radiogenic heat production in the coastal plain sands of Ipokia, Dahomey Basin, Nigeria. MethodsX, 6, 1608-1616. https://doi.org/10.1016/j.mex.2019.07.006.

Ahmad A.A., 1998. Characteristics of aerial and ground radioactives of basement and sedimentary rocks in Egypt: Relations and natural cycle across geologic time. [in:] El-Mashri S.M. (ed.), Proceedings of the third Arab conference on the peaceful uses of atomic energy, Arab Atomic Energy Agency, Tunis, 153-184.
Aisabokhae J.E., 2019. Geophysical classification of the basement complex of Kebbi State, northwestern Nigeria. Department of Earth Sciences, Faculty of Science, Adekunle Ajasin University, Akungba, Nigeria [Ph.D. thesis].

Aisabokhae J.E. \& Oresajo B., 2019. The magnetic response of hydrothermal alteration in iron-oxide basement complex, NW Nigeria. Geology, Geophysics and Environment, 45, 2, 145-156. http://dx.doi.org/10.7494/ geol.2019.45.2.145.

Allan K.A., Abou B.A. \& Taha, A., 2013. Dose assessment for natural radioactivity resulting from tiling granite rocks. Radiation Protection and Environment, 36, 3, 99-105. https://doi.org/10.4103/0972-0464.137471.

Amadi A.N., 2012. Radiometric survey as a useful tool in geological mapping of western Nigeria. Journal of Geography and Geology, 4, 1, 242-249. http://dx.doi.org/10.5539/ jgg.v4nlp242.

Beamish D. \& Busby J., 2016. The Cornubian geothermal province: heat production and flow in SW England: estimates from boreholes and airborne gamma-ray measurements. Geothermal Energy, 4, 4, 2-25. https://doi. org/10.1186/s40517-016-0046-8.

Bello S., Zakari Y.I., Muhammad B.G., Chiromawa N.L. \& Saribu A.Y., 2016. Environmental radioactivity assessment of Dana steel limited dump site, Katsina State, Nigeria. Journal of Natural and Applied Science, 5, 2, 159-166.

Cermak V., Huckenholz H.G., Rybach L. \& Schmid R., 1982. Radioactive heat generation in rocks. [in:] Hellwege K. (ed.), Landolt-Bornstein numerical data and functional relationships in science and technology. Sub-volume b. Physical Properties of Rocks, New Series; Group V, Geophysics and Space Research, Heidelberg, New York, 49-94.

Darnley A.G., 1973. Airborne gamma-ray survey techniques, present and future in uranium exploration methods. [in:] Uranium Exploration Methods: Proceedings of a Panel on Uranium Exploration Methods Held in Vienna 10-14 April 1972, Panel Proceedings Series, International Atomic Energy Agency, Vienna, 67-106.

Dentith M. \& Mudge S.T., 2014. Geophysics for the Mineral Exploration Geoscientist. Cambridge University Press, Cambridge.

Elkhadragy A.A., Abdelaziz A.M.S., Gharieb A.G.N. \& El Husseiny A.A., 2016. The use of airborne spectrometric data in geological mapping and uranium exploration at Qena-Quseir Shear Zone Area, Eastern Desert, Egypt. Global Journal of Science Frontier Research in Environmental Earth Sciences, 16, 5, 1-21.

Fitches W.R., Ajibade A.C., Egbuniwe I.G., Holt R.W. \& Wright J.B., 1985. Late Proterozoic schist belts and plutonism in NW Nigeria, Journal of Geological Society London, 142, 319-337.

Garba I., 2003. Geochemical characteristics of mesothermal gold mineralization in Pan-African $(600 \pm 150 \mathrm{Ma})$ basement of Nigeria. Applied Earth Science, 112, 319-325.

Gatis N., Luscombe D.J, Carless D., Parry L.E., Fyfe R.M., Harrod T.R., Brazier R.E. \& Anderson K., 2019. Mapping upland peat depth using airborne radiometric and lidar survey data. Geoderma, 335, 78-87. https://doi. org/10.1016/j.geoderma.2018.07.041.

Gillespie M.R., Crane E.J. \& Barron H.F., 2013. Deep geothermal energy potential in Scotland. British Geological Survey Agency commissioned report, CR/12/121, Keyworth, Nottingham, UK. 
Girigisu S., Ibeanu G., Adeyemo D.J., Onoja R.A., Bappah I.A. \& Okoh S., 2013. Assessment of radiological levels in soils from artisanal gold mining exercises at Awwal, Kebbi State, Nigeria. Research Journal of Applied Sciences, Engineering and Technology, 7, 14, 2899-2904. https://doi.org/10.19026/rjaset.7.618.

Huston D.L., 2010. An assessment of the uranium and geothermal potential of North Queensland. Geoscience Australia, Record 2010/14.

IAEA, 2003. Guidelines for radioelement mapping using gamma ray spectrometry data. IAEA-TECDOC-1363, International Atomic Energy Agency, Vienna, Austria.

Ibrahim U., Akpa T.C. \& Daniel I.H., 2013. Assessment of radioactivity concentration in soil of some mining areas in Central Nasarawa State, Nigeria. Science World Journal, 8, 2, 7-12.

Kogbe C., 1979. Geology of the south-eastern sector of the Iullemmeden Basin. Bulletin of Department of Geology, Ahmadu Bello University, Zaria, 2, 1, 34-78.

Manger E.G., 1963. Porosity and Bulk Density of Sedimentary Rocks. Geological Survey Bulletin, 1144, United States Printing Office, Washington.

Middleton M.F., 2016. Radiogenic heat generation in Western Australia - Implication for geothermal energy. [in:] Ismail B.I. (ed.), Advances in Geothermal Energy, IntechOpen, 49-90. http://dx.doi.org/10.5772/61963.

Mukai M., Yamaguchi T., Komura K., Furumoto M. \& Nagao T., 1999. Measurement of radioactive heat generation in rocks by means of gamma ray spectrometry. Proceedings of Japanese Academy, 75, 7, 181-185.

Norden B. \& Forster A., 2006. Thermal conductivity and radiogenic heat production of sedimentary and magmatic rocks in the northeast German basin. AAPG Bulletin, 90 , 6, 939-962. https://doi.org/10.1306/01250605100.

Ogezi A.E.O., 1977. Geochemistry and geochronology of basement rocks from northwestern Nigeria. Department of Geology, University of Leeds, United Kingdom [Ph.D. thesis].

Olasunkanmi N., Bamigboye O., Saminu O., Salawu N. \& Bamidele T., 2020. Interpretation of high resolution aeromagnetic data of Kaoje and environ, western part of the Zuru schist belt, Nigeria: implication for Fe-Mn occurrence. Heliyon, 6, e03320, 1-10. https://doi.org/10.1016/ j.heliyon.2020.e03320.

Rahaman M.A. 1988. Recent advances in the study of the basement complex of Nigeria. [in:] Oluyide P.O., Mbonu W.C., Ogezi A.E.O., Egbuniwe I.G., Ajibade A.C. \& Umeji A.C. (eds.), Precambrian Geology of Nigeria, Geological Survey of Nigeria Publication, Kaduna, 11-43.

Ramadan T.M. \& Abdel Fattah M.F., 2010. Characteristics of gold mineralization in Garin Hawal area, Kebbi State, NW Nigeria, using remote sensing. The Egyptian Journal of Remote Sensing and Space Science, 13, 153-163. https:// doi.org/10.1016/j.ejrs.2009.08.001.
Rawlins B.G., Lark R.M. \& Webster R., 2007. Understanding airborne radiometric survey signals across part of eastern England. Earth Surface Processes, 32, 1503-1515. https://doi.org/10.1002/esp.1468.

Reda A.Y., El Qassas M., Salaheldin S.M. \& Assran T., Abdel Fattah A. \& Rashed M.A., 2020. Airborne gamma-ray spectrometric data interpretation on Wadi Queih and Wadi Safaga area, Central Eastern Desert, Egypt. NRIAG Journal of Astronomy and Geophysics, 9, 1, 155-167. https://doi.org/10.1080/20909977.2020.1728893.

Rybach L., Werner D., Mueller S. \& Berset G., 1977. Heat flow, heat productionand crustal dynamics in the Central Alps, Switzerland. Tectonophysics, 41, 113-126.

Sabra M.E., Abdeldayem A.L., Youssef A.S., Masoud A.A. \& Mansour S.A., 2019. Determination of the radiation dose rate and radiogenic heat production of North Gabal Abu Hibban area, central Eastern Desert, Egypt. NRIAG Journal of Astronomy and Geophysics, 8, 1, 103-111.

Salem A., Elsirafy A., Sachio E. \& Ushijima K., 2005. Mapping radioactive heat production from airborne spectral gamma-ray data of Gebel Duwi area, Egypt. [in:] Proceedings of the World Geothermal Congress 2005: Antalya, Turkey, 24-29 April 2005. Geothermal energy, the domestic, renewable, green option, International Geothermal Association, Auckland, 1-6.

Samwell O., 2010. Radiometric survey and estimation of radiation exposure from Archean rocks: A case study of Migori gold belt company, Kenya. School of Pure and Applied Sciences, Kenyatta University, Kenya [M.Sc. thesis].

Saxov S. \& Abrahamsen N., 1964. Some rock densities in Bornholm. Geologiska Foreningen Stockholm Forhandlinger, 86, 1, 83-95. https://doi.org/10.1080/11035897.1964.9626368.

Scott B.R., 2007. Health Risk Evaluations for Ingestion Exposure of Humans to Polonium-210. Dose-Response. Publication of International Hormesis Society, 5, 94-122.

Slagstad T., 2008. Radiogenic heat production of Archean to Permian geological provinces in Norway. Norwegian Journal of Geology, 88, 149-166.

Usikalu M.R., Rabiu A.B., Oyeyemi K.D., Achuka J.A. \& Maaza M., 2017. Radiation hazard in soil from Ajaokuta, North Central, Nigeria. International Journal of Radiation Research, 15, 2, 219-224. https://doi.org/10.18869/ acadpub.ijrr.15.2.219.

Vila M., Fernandez M. \& Jimenez-Munt I., 2010. Radiogenic heat production variability of some common lithological groups and its significance to lithospheric thermal modelling. Tectonophysics, 490, 152-164. https://doi. org/10.1016/j.tecto.2010.05.003.

Wang N., Xiao L., Li C., Huang Y., Pei S., Liu S., Xie F. \& Cheng Y., 2005. Determination of radioactivity level of $\mathrm{U}$, Th and $\mathrm{K}$ in surface medium in Zhuhai City by in-situ gamma-ray spectrometry. Journal of Nuclear Science and Technology, 42, 10, 888-896. https://doi.org/10.1080/188 1124B.2005.9711040. 